\title{
Prospective Pre-School Teachers' Attitudes towards Astronomy
}

\author{
Cumhur Türk ${ }^{1, *} \&$ Esra Demir ${ }^{1}$ \\ ${ }^{1}$ Pre-school Education Program, Faculty of Education, Muş Alparslan University, Muş, Turkey \\ *Correspondence: Pre-school Education Program, Faculty of Education, Muş Alparslan University, Muş 49250, \\ Turkey. Tel: 90-436-249-4949. E-mail: c.turk@alparslan.edu.tr
}

Received: October 17, 2016

Accepted: November 29, 2016 Online Published: December 12, 2016

doi:10.5430/wje.v6n6p60

URL: http://dx.doi.org/10.5430/wje.v6n6p60

\begin{abstract}
The purpose of this study is to examine the changes in prospective pre-school teachers' attitudes towards astronomy in terms of their grades. The study was conducted with 205 prospective teachers $\left(1^{\text {st }}, 2^{\text {nd }}, 3^{\text {rd }}, 4^{\text {th }}\right.$ graders $)$ studying in the education faculty of a university in Eastern Anatolia region of Turkey. Astronomy Attitude Scale (AAS) was used as data collection instrument. One-Way Anova was used for independent groups in data analysis in order to find out whether prospective pre-school teachers' attitudes towards astronomy differed in terms of their grades. Data analysis results showed that prospective pre-school teachers' attitudes towards astronomy did not differ significantly in terms of their grades. In addition, it was concluded that while prospective pre-school teachers had positive attitudes such as associating astronomy with daily life, thinking that astronomy can be learned better through applied activities and contemporary developments about astronomy attracted their attention, they also had negative attitudes such as feeling insecure about astronomy subjects and not liking the field of astronomy. In line with these results, it was recommended that the number of physical sciences lessons in pre-school teaching departments in education faculties should be increased.
\end{abstract}

Keywords: astronomy education; attitude; pre-school teacher

\section{Introduction}

The concept of attitude is the tendency of giving learned positive or negative reactions to specific objects, situations, institutions, concepts or other people (Koballa, 1988). Individuals' attitudes are not visible; however, one can have information about an individual's attitudes by watching his/her behaviors (Morgan, 1991). If the attitudes towards an object or an event are positive, it is more likely that the decisions about that object or event will also be positive. Thus, attitudes have the characteristics of future decisions (Tavşancıl, 2002; Ülgen, 1995). Attitudes can be learned through direct experiences or observations of people about events, or through the information they acquire (Shrigley, Koballa \& Simpson, 1988). In the process of education, measuring attitudes provides benefits such as predicting learners' future behaviors by finding out his/her attitudes within a specific time and finding out learners' attitudes about the conditions they are in. Thus, individuals' attitudes can be described scientifically and they can be led to better by predicting behavior (Baysan \& Tekarslan, 1998).

It can be said that while individuals' attitudes can determine their future success, their success in the past shapes their attitudes (Altınok, 2004; Kozcu-Çakır, Şenler \& Göçmen-Taşkın, 2007). In their study, Rennie \& Punch (1991) found that success and attitudes in science lesson were associated with each other. Similarly, Kozcu-Çakır et al. (2007) and Turhan, Aydoğdu, Şensoy \& Yıldırım (2008) found a positive association between attitudes towards science lesson and success.

When the literature is reviewed, a great number of researches can be seen that have examine the attitudes of individuals towards science within the process of education. It is remarkable that these studies are oriented toward physical sciences (Geban et al., 1994; Kind, Jones \& Barmby, 2007; Nuhoğlu, 2008), physics (Reid \& Skrybina, 2002; Kurnaz \& Yiğit, 2010), chemistry (Şimşek, 2002; Hançer \& Uludağ, 2007), biology (Kocaoğlu \& Türkmen, 2010; Pehlivan \& Köseoğlu, 2010) and laboratory (Budak, 2001; Ekici, 2002; Nuhoğlu \& Yalçın, 2004). The numbers of studies oriented at attitudes towards astronomy are relatively limited when compared with the number of studies on other disciplines. 
When studies about astronomy education are examined, it can be seen that studies are generally oriented towards finding out students' academic achievement or misconceptions (Bisard, Aron, Francek \& Nelson, 1994; Kalkan \& Kıroğlu, 2007; Trumper, 2001a; 2001b, 2001c; Zeilik, Schau \& Mattern, 1998). Except these studies, there are very few studies which have focused on finding out students' perceptions towards science (Zeilik, Schau \& Mattern, 1999; Zeilik \& Morris, 2003; Jarvis \& Pell, 2005; Uçar \& Demircioğlu, 2011; Okulu \& Oğuz-Ünver 2011). Among these studies, there are hardly any which have focused on prospective pre-school teachers or pre-school students (Çakmak, 2012). In their study conducted with 407 science teachers, Uçar and Demircioğlu (2011) found that activities about the Moon did not change prospective pre-school teachers' attitudes towards astronomy. Another study conducted to find out prospective teachers' attitudes towards astronomy was conducted by Okulu and Oğuz-Ünver (2011). In this study, which was conducted with a total of 193 prospective science, social sciences and primary school teachers concluded that the attitudes of prospective teachers towards astronomy were moderate in general.

Individuals who have received astronomy education can comprehend the significance and vitality of physical sciences better because it helps individuals to comprehend better that astronomy is the most important key in helping an individual position himself within the universe, to understand the environment they live in better, to shape and facilitate science and life (Martin, Sexton, Franklin \& Gerlovich, 2005). For contemporary societies, developing positive attitudes towards astronomy is an important part of science literacy (Uçar \& Demircioğlu, 2011).

Based on all these studies, a need was felt to find out how the attitudes of prospective pre-school teachers, who are responsible for teaching astronomy subjects in pre-school, changed during their university education. While doing this, it was thought that unlike other studies, it would be beneficial to conduct a cross-sectional study, since it was not found to be studied a lot in literature. For these reasons, unlike other studies in literature, this study was planned not only to present the existing situation about prospective teachers, but also to observe the change. In addition, the fact that there are no studies in literature about the attitudes of prospective pre-school teachers towards astronomy shows the significance of this study for literature.

\subsection{The Purpose of the Study and Research Questions}

The purpose of this study is to examine the changes in prospective pre-school teachers' attitudes towards astronomy in terms of their grades. The problem statement of this study, which was planned in line with this purpose, is as follow:

"How are the changes in prospective pre-school teachers' attitudes towards astronomy in terms of their grades?"

In accordance with this research question, it is sought for answers to following sub-questions;

1. Is there a significant difference in prospective pre-school teachers' attitudes in terms of their grades?

2. Is there a significant difference between prospective pre-school teachers' attitudes towards astronomy and their grades in terms of sub factors?

\section{Method}

This study used survey method, which is descriptive method, in finding out the differences between prospective pre-school teachers' attitudes towards astronomy in terms of their grades. Survey is a research method which is conducted to find out the existing states in studies. Answers are sought to the question of what the existing state of an event or problem is or the question of "where are we?" (Çepni, 2007).

\subsection{Sample}

The sample of the study consisted of prospective pre-school teachers(Note) studying in the education faculty of a university chosen from Eastern Anatolia region of Turkey during the 2016-2017 academic year. Simple random sampling method was used to determine the sample in the study. The information about the sample is given in Table 1. 
Table 1. The Distribution of the Research Sample According to Grade

\begin{tabular}{cccccc}
\hline \multirow{2}{*}{ Gender } & \multicolumn{4}{c}{ Prospective Pre-school Teacher } & \multirow{2}{*}{ Total } \\
\cline { 2 - 5 } & $\mathbf{1}^{\text {st }} \mathbf{G r a d e}$ & $\mathbf{2}^{\text {nd }} \mathbf{G r a d e}$ & $\mathbf{3}^{\text {rd }}$ Grade & $\mathbf{4}^{\text {th }}$ Grade & \\
\hline Female & 32 & 29 & 51 & 52 & $\mathbf{1 6 4}$ \\
Male & 8 & 11 & 9 & 13 & $\mathbf{4 1}$ \\
Total & $\mathbf{4 0}$ & $\mathbf{4 0}$ & $\mathbf{6 0}$ & $\mathbf{6 5}$ & $\mathbf{2 0 5}$ \\
\hline
\end{tabular}

\subsection{Data Collection Instrument}

Within the context of the study, "AAS" which was developed by Türk \& Kalkan (2015) was used as the data collection tool. AAS is a valid and reliable scale developed to measure students' attitudes towards astronomy by Türk \& Kalkan (2015). AAS is a 5-likert type scale, consisting of 5 sub factors and 27 items with 0,912 reliability (Cronbach's Alpha).

\subsection{Data Analysis}

SPSS 23.0 statistical program was used from the qualitative data obtained from AAS. Before statistical analyses were conducted, descriptive statistics were calculated for total scores of prospective teachers from the scale. In order to find out which of the analysis techniques- parametric/non-parametric would be used in data analysis, "normality distribution of the data" and "whether the sample was more than/less than 30 people" were examined

While determining the analysis technique of quantitative data, the data should be tested for having normal distribution. If the data have a normal distribution, parametric tests are used in analysis. The second point to take into consideration is the number of people to compare in groups. If the number of participants in groups is more than 30 , it is possible to use parametric tests assuming that the results obtained from the data will be distributed normally (Can, 2014). The number of prospective teachers in this study is more than 30 . Thus, the criterion that required more than 30 participants for parametric tests was met. Normality tests were conducted to test whether the data were normally distributed, which was another criterion. Table 2 gives the normality results of AAS.

Table 2. The Results of Normality Test

\begin{tabular}{|c|c|c|c|}
\hline & \multicolumn{3}{|c|}{ Kolmogorov-Smirnov } \\
\hline & Statistic & df & $\mathbf{p}$ \\
\hline AAS & ,061 & 205 &, $060^{*}$ \\
\hline
\end{tabular}

When Table 2 is examined, it can be seen that the data are normally distributed. Based on this, it can be said that it meets one of the criteria required for using parametric analysis techniques in the analysis of AAS data.

Levene test, variance homogeneity, was conducted on AAS total scores of prospective teachers. The results of this test are given in Table 3.

Table 3. The Results of Levene Test

\begin{tabular}{ccccc}
\hline & $\mathbf{F}$ & $\mathbf{S d}_{\mathbf{1}}$ & $\mathbf{S d}_{\mathbf{2}}$ & $\mathbf{p}$ \\
\hline $\mathbf{A A S}$ &, 493 & 1 & 203 &, $688^{*}$ \\
\hline$*_{\mathrm{p}>}>05$ & & &
\end{tabular}

In line with the results in Table 3, no significant difference was found between the variances of prospective teachers' AAS scores $\left(\mathrm{F}_{(1,203)}=, 493 ; \mathrm{p}>, 05\right)$.

Box's M test was used to examine the covariance equality for total scores from AAS and the results were given in Table 4. 
Table 4. The Equality of the Covariance Matrix for AAS Scores

\begin{tabular}{cccccc}
\hline & Box's M & F & Sd $_{\mathbf{1}}$ & Sd $_{\mathbf{2}}$ & p \\
\hline AAS & 84,102 & 1,259 & 63 & 68890,863 & $0,80^{*}$ \\
\hline$*_{\mathrm{p}>}>05$ & & & &
\end{tabular}

Covariance equality of groups to find out the significance in AAS total scores was tested and it was found that the covariances $(p>, 05)$ were homogeneous.

Before the analysis of parametric data, it was examined whether the assumptions of ANOVA technique to be used during the analysis process met the assumptions or not. The assumptions stated by Büyüköztürk (2010) were found to meet. The assumptions met were as follows:

- $\quad$ AAS is an equally spaced score.

- The scores of the dependent variable have normal distribution (see Table2).

- Variances of prospective teachers are homogenous (See. Table 3).

- Covariance of the groups are equal for the double combinations of the data (See. Table 4).

- The difference score calculated for any prospective teacher in the sample is independent from the difference score calculated for another prospective teacher.

One way variance analysis (One-Way Anova) technique was used to find out whether there was significant difference between the AAS scores of prospective teachers in terms of their grades. One way variance analysis is used to find out whether the difference between the averages of two or more unrelated samples is different from zero significantly (Büyüköztürk, 2005; Can, 2014). The level of significance was taken as 0,05 while interpreting the statistical analyses results.

\section{Findings}

AAS findings were presented in sub-titles. First, One-Way Anova results about whether there were differences between grade and the total score from AAS were presented. Next, One-Way Anova results about whether there were significant differences between total scores from each sub-factor of AAS and grades.

\subsection{Findings of $A A S$}

The mean and standard deviations by grade for prospective pre-school teachers' AAS scores are shown in Table 5.

Table 5. Descriptive Statistics of AAS

\begin{tabular}{ccccccc}
\hline Grade & N & SD & Mean & $\begin{array}{c}\text { Number } \\
\text { of Items }\end{array}$ & $\begin{array}{c}\text { Mean / Number } \\
\text { of Items }\end{array}$ & Attitude \\
\hline $\mathbf{1}^{\text {st }}$ & 40 & 12,25320 & 92,2500 & 27 & 3,42 & Indecisive - Agree \\
$\mathbf{2}^{\text {nd }}$ & 40 & 20,04250 & 93,1250 & 27 & 3,45 & Indecisive - Agree \\
$\mathbf{3}^{\text {rd }}$ & 60 & 16,31140 & 93,8500 & 27 & 3,48 & Indecisive - Agree \\
$\mathbf{4}^{\text {th }}$ & 65 & 15,49266 & 93,2923 & 27 & 3,46 & Indecisive - Agree \\
\hline
\end{tabular}

When Table 5 is examined, some findings can be seen about the averages and standard deviations of the answers given by prospective teachers to our 5 likert-type scale were given. First of all, it was found that there weren't many changes in the attitudes scores of prospective pre-school teachers towards astronomy and first grades were found to be relatively behind other class levels. Secondly, general attitudes (mean/number of items) of prospective teachers in terms of each grade level were not found to be very high. The fact that general attitudes differed between 3,42 and 3,48 makes it difficult to say that prospective teachers' attitudes are positive. In 5-likert type scaling, in measurements based on average scores per item, scores between 1.00-1.80 can be commented as totally disagree, 1.80-2.60 can be commented as disagree, 2.60-3.40 can be commented as indecisive, 3.40-4.20 can be commented as agree and 4.20-5.00 can be commented as totally agree. Thus, it can be said that prospective teachers' attitudes 
scores which are between 3,42 and 3,48 can be said to be at the threshold of the attitude scores of "indecisive" and "agree".

One way variance analysis was conducted to find out whether the change in AAS scores of prospective teachers in terms of grade differed statistically significantly. The results of this analysis were given in Table 6 .

Table 6. One Way Variance Analysis of AAS Scores

\begin{tabular}{lccccc}
\hline Source of variance & $\begin{array}{c}\text { Sum of } \\
\text { squares }\end{array}$ & df & $\begin{array}{c}\text { Mean } \\
\text { square }\end{array}$ & F & p \\
\hline $\begin{array}{l}\text { Between Groups } \\
\text { (Grade) }\end{array}$ & 62,151 & 3 & 20,717 &, 079 &, 971 \\
Within Groups & 52580,971 & 201 & 261,597 & & \\
Total & 52643,122 & 204 & & & \\
\hline
\end{tabular}

According to Table 6, no significant difference was found between the average AAS scores of prospective teachers in terms of grade $\left(\mathrm{F}_{3-204}=20,717, \mathrm{p}>, 05\right)$. This result can be commented as there were no changes in prospective pre-school teachers' attitudes towards astronomy in terms of their grades.

\subsection{Findings of AAS Sub-factors}

Prospective pre-school teachers' attitudes towards astronomy were examined in terms of sub-factors. AAS is a scale that consists of five sub-factors. These sub-factors are "daily life, application, being interested, self-confidence and liking". Descriptive statistics that were prepared based on the total scores of AAS's sub-factors are given in Table 7.

Table 7. Descriptive Statistics Based on the Sub-Factors of AAS

\begin{tabular}{ccccccc}
\hline Factor & N & $\begin{array}{c}\text { Number } \\
\text { of Items }\end{array}$ & SD & Mean & $\begin{array}{c}\text { Mean / } \\
\text { Number } \\
\text { of Items }\end{array}$ & Attitude \\
\hline Daily life & 205 & 10 & 7,31807 & 30,5317 & 3,53 & Agree \\
Application & 205 & 5 & 2,89273 & 17,9317 & 3,59 & Agree \\
Being interested & 205 & 6 & 4,26422 & 21,3317 & 3,55 & Agree \\
Self-confidence & 205 & 4 & 2,87993 & 13,2098 & 3,30 & Indecisive \\
Liking & 205 & 2 & 2,01699 & 6,5805 & 3,29 & Indecisive \\
\hline
\end{tabular}

When Table7 was examined, it was found that prospective teachers' attitudes about the sub-factors of "self-confidence" and "liking" were at the level of "indecisive", while their attitudes about the sub-factors of "daily life", "application" and "being interested" were at the level of "agree". The sub-factor that students showed the lowest attitude was "liking". This result shows that prospective pre-school teachers did not have positive attitudes about liking the field of astronomy. The sub-factor prospective teachers showed the highest attitude was "application". This result shows that prospective pre-school teachers had positive attitudes that they could learn about astronomy subjects better and easier with practices. In other words, prospective teachers support positively that astronomy subjects should be taught not theoretically but with practical activities. In addition, while prospective teachers had positive attitudes about the thought of astronomy being directly associated with daily life and being interested in astronomy subjects, they had an attitude at the level of "indecisive" about their self-confidence about astronomy subjects.

One way variance analysis was conducted to find out whether the total scores of AAS differed significantly in terms of their grades. The results of this analysis are in Table 8. 
Table 8. One Way Variance Analysis of AAS Sub-Factor Scores

\begin{tabular}{|c|c|c|c|c|c|c|}
\hline Factor & Source of variance & $\begin{array}{l}\text { Sum of } \\
\text { squares }\end{array}$ & df & $\begin{array}{l}\text { Mean } \\
\text { square }\end{array}$ & $\mathbf{F}$ & $\mathbf{p}$ \\
\hline \multirow{3}{*}{ 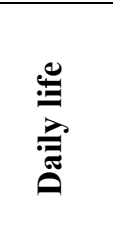 } & $\begin{array}{l}\text { Between Groups } \\
\text { (Grade) }\end{array}$ & 79,022 & 3 & 26,341 & \multirow[t]{3}{*}{,488 } & \multirow[t]{3}{*}{,691 } \\
\hline & Within Groups & 10846,022 & 201 & 53,960 & & \\
\hline & Total & 10925,044 & 204 & & & \\
\hline \multirow{3}{*}{ 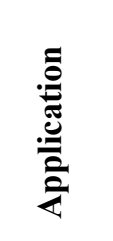 } & $\begin{array}{l}\text { Between Groups } \\
\text { (Grade) }\end{array}$ & 32,020 & 3 & 10,673 & \multirow[t]{3}{*}{1,281} & \multirow[t]{3}{*}{,282 } \\
\hline & Within Groups & 1675,024 & 201 & 8,333 & & \\
\hline & Total & 1707,044 & 204 & & & \\
\hline \multirow{3}{*}{ 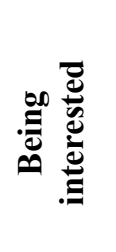 } & $\begin{array}{l}\text { Between Groups } \\
\text { (Grade) }\end{array}$ & 20,672 & 3 & 6,891 & \multirow[t]{3}{*}{,375 } & \multirow[t]{3}{*}{,771 } \\
\hline & Within Groups & 3688,772 & 201 & 18,352 & & \\
\hline & Total & 3709,444 & 204 & & & \\
\hline \multirow{3}{*}{ 岕 } & $\begin{array}{l}\text { Between Groups } \\
\text { (Grade) }\end{array}$ & 25,601 & 3 & 8,534 & \multirow[t]{3}{*}{1,029} & \multirow[t]{3}{*}{,381 } \\
\hline & Within Groups & 1666,379 & 201 & 8,290 & & \\
\hline & Total & 1691,980 & 204 & & & \\
\hline \multirow{3}{*}{ 哭 } & $\begin{array}{l}\text { Between Groups } \\
\text { (Grade) }\end{array}$ & 12,547 & 3 & 4,182 & \multirow[t]{3}{*}{1,028} & \multirow[t]{3}{*}{, 381} \\
\hline & Within Groups & 817,375 & 201 & 4,067 & & \\
\hline & Total & 829,922 & 204 & & & \\
\hline
\end{tabular}

When Table 8 is examined, the most general result found is that prospective teachers' attitudes about the sub-factors of AAS did not differ significantly as the students' grade changed. In other words, prospective teachers in different grades have the same level of attitude in terms of the sub-factors of "daily life, application, being interested, self-confident and liking".

\section{Discussion and Conclusion}

The analyses conducted for the first problem statement of the study "are there significant changes in prospective teachers' attitudes toward astronomy in terms of the level of grade" clearly show that no significant changes occur in the general attitude scores of prospective teachers towards astronomy. In addition, general attitude scores which are between 3,42 and 3,48 in prospective teachers' general attitude scores show that their scars are in-between the attitude scores of "indecisive". This result can be commented as a reflection of the teaching education prospective pre-school teachers experienced at university because prospective pre-school teachers do not get astronomy lesson directly during their hearing education. Only within the "science teaching" lesson which is in the undergraduate program of pre-school teaching, they can learn some astronomy subjects and concepts. However, since this lesson comprises all science subjects in terms of content, the time allocated to disciplines such as astronomy, physics, chemistry and biology is limited. This situation may cause students not to eliminate their lack of knowledge in disciplines such as astronomy, physics, chemistry and biology. The results found in our study supports this thought in terms of the discipline of astronomy because there were no differences between students' attitudes toward astronomy while starting their program and their attitudes four years later. Similarly, in Türk (2016)'s study, a cross-sectional study was conducted on prospective science teachers about their attitudes toward astronomy and their 
success. When the attitudes and success of $1^{\text {st }}, 2^{\text {nd }}, 3^{\text {rd }}$ and $4^{\text {th }}$ grade science teaching students were examined, it was found that the attitudes and success of prospective teachers changed positively. It was found that the students' attitudes and success within the process did not change until they got astronomy lesson at grade 4 , and after $4^{\text {th }}$ grade astronomy lesson, attitudes and success of prospective teachers developed significantly after grade 4 astronomy lesson. In addition, a positive and significant association was found between astronomy success and astronomy oriented attitudes. Considering this, low levels of prospective pre-school teachers' attitudes towards astronomy and no changes in this for 4 years, not getting any astronomy classes can be causes by the fact that they did not get any astronomy classes during their university education and their insufficient information about this. In line with this view, Kind et al. (2007) stated that the positive attitudes of a student towards a lesson are in line with the success the children get from that class. Similarly, in the study Çakmak (2012) examined the association between prospective pre-school teachers' attitudes towards science teaching and levels of comprehending some scientific concepts, a positive statistically significant association was found between two variables.

The results of the answers to the question "are there differences between prospective teachers' attitudes towards astronomy in terms of sub-factors and their grades" put forward the result that there is no statistically significant difference the five sub-factors. In addition, the sub-factors of "liking" and "self-confidence are factors in which prospective teachers did not show positive attitude. The sub-factors of "daily life", "application" and "being interested" were found to be factors prospective teachers showed relatively positive attitudes. According to these results, it can be said that while prospective pre-school teachers had positive attitudes such as associating astronomy with daily life, thinking that astronomy can be learned better through applied activities and contemporary developments about astronomy attracted their attention, they also had negative attitudes such as feeling insecure about astronomy subjects and not liking the field of astronomy. Once attitudes are formed, they do not change easily (Ajzen \& Fishbern, 1980). Considering this, our results are very important because negative attitudes of prospective pre-school teachers will continue when they start their occupation, too. Thus, it will be difficult for students educated by them to have positive attitudes. However, pre-school teachers are curious and interested in concepts related with astronomy. Some studies show that children are interested in earth, sun, moon and sky starting from small ages. It is very important to develop the questions and attitudes about children at this age in a positive way. Otherwise, misconceptions and negative attitudes that are difficult to change in the future occur. In addition, according to Wittman (2009), thanks to the positive attitude towards astronomy, students will also develop positive attitudes towards physical sciences. Thus, the positive attitudes towards astronomy are not important only in term of astronomy, but also in terms of physical sciences. Otherwise, prospective pre-school teachers will direct towards non-scientific knowledge and do not understand the nature of physical sciences. Kallery (2010) showed that $60 \%$ of prospective pre-school teachers who did not have positive attitudes towards astronomy believed astrology was scientific and 59\% thought that astronomy and astrology were the same. All these results show that thanks to positive attitudes towards astronomy, prospective pre-school teachers will be able to comprehend scientific thinking and the nature of physical sciences.

\section{Research Limitations and Future Directions}

- The results show that the "Science teaching" lesson in the curriculum of undergraduate pre-school teaching program is not enough for prospective teachers to develop positive attitudes towards astronomy. Thus, it will be of use to increase the number of "science teaching" lessons within the pre-school teaching undergraduate program.

- This study was planned cross-sectional. While this situation saves time, it has limitations such as not being able to take data from the same person with different intervals of time. Thus, longitudinal studies which will present the changes in prospective teachers' astronomy attitudes towards astronomy by taking measurements at different grades of study from the same sample can be conducted.

- Another limitation of the study is the fact that there are a great number of different socio-economic and cultural regions and schools in Turkey; it is difficult to make generalizations from the results of this study. This study can be implemented on universities of different socio-cultural structure; the results may be generalized and solutions may be recommended accordingly.

\section{References}

Ajzen, I., \& Fishbein, M. (1980). Understanding attitudes and predicting social change. New Jessey: Prentice-Hill. Altınok, H. (2004). The attitudes of fifth graders towards the science course in terms of gender and achievement. 
Eurasian Journal of Educational Research, 17, 81-91.

Baysan, C., \& Tekarslan, E. (1998). Behavioral sciences. İstanbul: Istanbul University Business Administration Publications.

Bisard, W. J., Aron, R. H., Francek, M. A., \& Nelson, B. D. (1994). Assessing selected physical science and earth science misconceptions of middle school through university pre-service teachers: Breaking the science 'misconception cycle'. Journal of College Science Teaching, 24(1), 38-42.

Budak, E. (2001). The effects of constructive teaching method on conceptual change, success, attitude and perceptions of students in university analytical chemistry laboratories. Gazi University Educational Sciences Institute, Master thesis, Ankara.

Büyüköztürk, Ş. (2005). Developing questionnaire. Turkish Journal of Educational Sciences, 3(2), 133-151.

Büyüköztürk, Ş. (2010). Handbook data analysis for social sciences: Statistics, research design, SPSS and comments. Ankara: Pegem A Publishing.

Çakmak, Ö. (2012). Investigation of the relationship between preschool teacher candidates' attitudes towards science teaching and the level of understanding some science concepts. Journal of Turkish Science Education, 9(3), 40-51.

Can, A. (2014). Quantitative data analysis with SPSS research process. (2nd ed.). Ankara: Pegem Academy.

Çepni, S. (2007). Introduction to research and project studies. Trabzon: Erol Offset.

Ekici, G. (2002). The attitude scale of biology teachers' laboratory lesson (ASBTTLL). Hacettepe University Journal of Education, 22, 62-66.

Geban, O., Ertepınar, H., Yılmaz, G., Atlan, A., \& Şahbaz, O. (1994). The impact of computer-aided education on students' achievement and science knowledge. I. National Science Education Symposium, Dokuz Eylül University, İzmir.

Hançer, A. H., \& Uludağ, N. (2007). The evaluation of the attitudes of science teacher candidates towards chemistry lesson. Hacettepe University Journal of Education, 32, 100-109.

Jarvis, T., \& Pell, A. (2005). Factors influencing elementary school children's attitudes to science before during and following a visit to the UK National Space Centre. Journal of Research in Science Teaching, 42(1), 53-83. https://doi.org/10.1002/tea.20045

Kalkan, H., \& Kıroğlu, K. (2007). Science and nonscience students' conceptions of basic astronomy concepts in preservice training for education teachers. Astronomy Education Review, 6(1). https://doi.org/10.3847/AER2007002

Kallery, M. (2011). Astronomical concepts and events awareness for young children. International Journal of Science Education, 33(3), 341-369. https://doi.org/10.1080/09500690903469082

Kind, P., Jones, K., \& Barmby, P. (2007). Developing attitudes towards science measures. International Journal of Science Education, 2(7), 871-893. https://doi.org/10.1080/09500690600909091

Koballa, T. R. (1988). The determinants of female junior high school students' intentions to enroll in elective physical sciences in high school: testing the applicability of the theory of reasoned action. Journal of Research in Science Teaching, 25, 479-492. https://doi.org/10.1002/tea.3660250605

Koçakoğlu, M., \& Türkmen, L. (2010). Developing a biology attitude scale. Ahi Evran University Journal of Kirşehir Faculty of Education, 11(2), 229-245

Kozcu-Çakır, N., Şenler, B., \& Göçmen-Taşkın, B. (2007). Determınıng the attitudes towards science course of second grade students in primary school. Journal of Turkish Educational Sciences, 5(4), 637-655.

Kurnaz, M. A., \& Yiğit, N. (2010). Physics attitude scale: Development, validity and reliability. Necatibey Faculty of Education Electronic Journal of Science and Mathematics Education, 4, 1-29.

Martin, R., Sexton, C., Franklin T., \& Gerlovich, J. (2005). Teaching science for all children an inquiry approach. Boston: Pearson Publishing.

Morgan, C. T. (1991). Introduction to Psychology. 8th Edition (Translated by Hüsnü Arıc1, Orhan Aydın et al.), Hacettepe University, Department of Psychology Publications, Ankara.

Nuhoğlu, H. (2008). The development of an attitude scale for science and technology course. Elementary Education Online, 7(3), 627-639. 
Nuhoğlu, H., \& Yalçın, N. (2004). The development of attitude scale for physics laboratory and the assessment of preservice teachers' attitudes towards physics laboratory. Gazi University Journal of Kırşehir Faculty of Education i (KEFAD), 5(2), 317-327.

Okulu, H. Z., \& Oğuz-Ünver, A., (2011). Determination of the teacher candidates' attitudes towards astronomy. Western Anatolian Journal of Educational Sciences, Special Issue WCNTSE, 107-112.

Pehlivan, H., \& Köseoğlu, P. (2010). Attitudes towards biology course and the academic self-concept of the students attending at Ankara Science High School. Hacettepe University Journal of Education), 38, 225-235.

Reid, N., \& Skryabina, E. A. (2002). Attitudes toward physics. Research in Science and Technology Education, 20(1), 67-81. https://doi.org/10.1080/02635140220130939

Rennie, L. J., \& Punch K. F. (1991). Relationship between affect and achievement in science, Journal of Research in Science Teaching, 28, 193-209. https://doi.org/10.1002/tea.3660280209

Shrigley, R.L., Koballa, T. R., \& Simpson, R. D. (1988). Defining attitudes for science educators. Journal of Research in Science Teaching, 25(8), 659-678. https://doi.org/10.1002/tea.3660250805

Şimek, N. (2002). Preparation of an attitude scale for chemistry education and making various evaluation. Hacettepe University Science Institute, Master Thesis, Ankara.

Tavşanc1l, E. (2002). Measuring attitudes and data analysis with SPSS. Ankara: Nobel Publications.

Trumper, R. (2001a). A cross-age study of junior high school students' conceptions of basic astronomy concepts. International Journal of Science Education, 23(11), 1111-1123. https://doi.org/10.1080/09500690010025085

Trumper, R. (2001b). A cross-age study of senior high school students' conceptions of basic astronomy concepts. Research in Science and Technological Education, 19(1), 97-109. https://doi.org/10.1080/02635140120046259

Trumper, R. (2001c). A cross-college age study of science and nonscience students' conceptions of basic astronomy concepts in preservice training for high-school teachers. Journal of Science Education and Technology, 10(2), 189-195. https://doi.org/10.1023/A:1009477316035

Turhan, F., Aydoğdu, M., Şensoy, Ö. \& Yıldırım, H. İ. (2008). The relationship between cognitive development levels of primary school 8th grade students, science achievement, attitudes towards science and gender variables. Kastamonu Education Journal, 16(2), 439-450.

Türk, C. (2016). The correlation between pre-service science teachers' astronomy achievement, attitudes towards astronomy and spatial thinking skills. Journal of Education and Learning, 5(2), 187. https://doi.org/10.5539/jel.v5n2p187

Türk, C., \& Kalkan, H. (2015). Astronomy attitude scale: Development, validity and reliability. Journal of Studies in Education, 5(4), 23-50.

Uçar, S., \& Demircioğlu, T. (2011). Changes in preservice teacher attitudes toward astronomy within a semester-long astronomy instruction and four-year-long teacher training programme. Journal Science Education Technology, 20(1), 65- 73. https://doi.org/10.1007/s10956-010-9234-7

Ülgen, G. (1995). Educational psychology. Ankara: Bilim Publications.

Wittman, D. (2009). Shaping attitudes toward science in an introductory astronomy course. The Physics Teacher, 47(9), 591-594. https://doi.org/10.1119/1.3264591

Zeilik, M., \& Morris, V. J. (2003). An examination of misconceptions in an astronomy course for science mathematics and engineering majors. Astronomy Education Review, 2(1), 101-119. https://doi.org/10.3847/AER2003005

Zeilik, M., Schau, C., \& Mattern, N. (1998). Misconceptions and their change in university level astronomy courses. The Physics Teacher, 36(2), 104-107. https://doi.org/10.1119/1.880056

Zeilik, M., Schau, C., \& Mattern, N. (1999). Conceptual astronomy II- replicating conceptual gains, probing attitude changes across three semesters. American Journal of Physics, 67(10), 923-927. https://doi.org/10.1119/1.19151

\section{Note}

Note 1. Pre-school teaching program in Turkey consists of 4 years. Therefore, students from year of study levels 1 st, 2nd, 3rd and 4th were incorporated for study. 